\title{
Creative Economy Potential through Typical Ulos Fabric Small Industries to Promote the Economy of Lumban Suhi-Suhi Village, (D) Toruan Samosir Regency
}

\author{
Annisa Ilmi Faried, Rahmad Sembiring
}

\begin{abstract}
The spirit of advancing the regional economy in creating regional creative endeavors with various innovations combined through a combination of motifs, colors, models in accordance with current developments without losing the characteristics of local culture so that the preservation of ulos woven cloth becomes the host in its own region. To be able to achieve these goals, the government and the community jointly take local development initiatives by using all the potential they have by not forgetting the culture that is the main base of regional creative economic development that includes the readiness of human resources, the availability of natural resources that foster innovation and creativity, creating entrepreneurs, and creating renewable resources for the welfare of society. The existence of this activity can produce a variety of products that can attract consumers. Bags, wallets, bracelets, hats and other accessories are the result of training of weaving craftsmen in Samosir Regency.
\end{abstract}

Keywords: Keywords: Ulos ${ }^{1}$, Industry ${ }^{2}$, Creative ${ }^{3}$, Regional ${ }^{4}$, Economy

\section{INTRODUCTION}

Ulos cloth identified with the Batak tribe has become a customary means to remember kinship in almost all traditional ceremonies, always using ulos as a source of warmth in the spiritual relationship of the Batak kinship, that is dalih na tolu. According to Marissa Cory (2016) [1] that in the life of the Batak tribe, ulos cloth plays an important role that is used in almost every daily activity of the community. For example, in thanksgiving activities, entering a new home, a ceremony for birth, death, and also marriage. Ulos in Batak means the word blanket. This is based because at the beginning of its creation, ulos cloth was used as a blanket.

Revised Manuscript Received on January 03, 2020.

* Correspondence Author

Annisa Ilmi Faried*, Lecturer Of Economy Development Study ProgramFaculty Of Social Science Universitas Pembangunan Panca Budi. Email : annisailmi@dosen.pancabudi.ac.id

Rahmad Sembiring, Lecturer Of Economy Development Study Program Faculty Of Social Science Universitas Pembangunan Panca Budi. Email : rahmadsembiring@dosen.pancabudi.ac.id

(C) The Authors. Published by Blue Eyes Intelligence Engineering and Sciences Publication (BEIESP). This is an open access article under the CC BY-NC-ND license (http://creativecommons.org/licenses/by-nc-nd/4.0/)

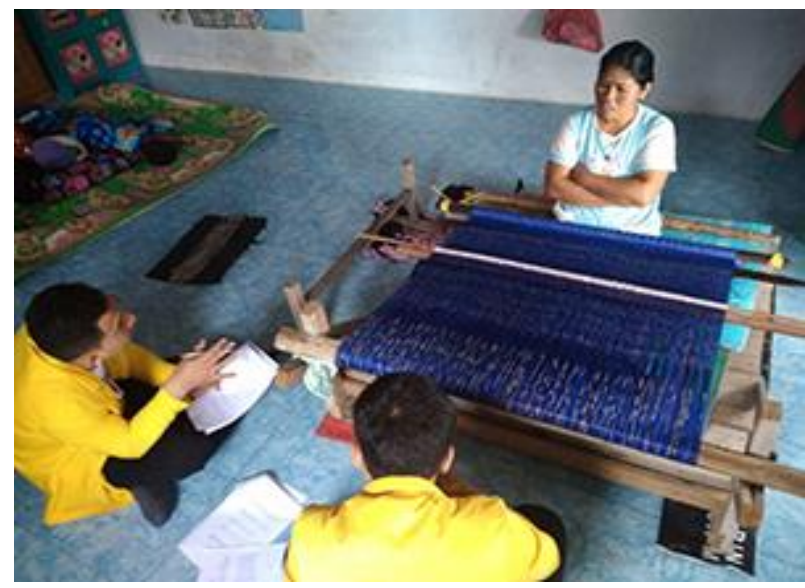

Picture 1.1 Traditional Looms (Ikat Weaving), 2019

From the picture above, the traditional loom used by the craftsmen in Lumban Suhi-Suhi Toruan Village is ikat weaving which has become a weaving tool that has been passed down from generation to generation. The material used in making this weaving is silk yarn, rayon yarn and suji yarn. Ulos fabric motifs can take up to weeks to make or it can take months depending on the demand, difficulty of the motif, and the size of the ulos to be woven by the ulos craftsman. This activity actually requires perseverance, patience, ideas, imagination and even a high sense of dedication to be able to preserve the typical Batak woven cloth. For just one piece of fabric requires thousands of threads of various colors desired by penun, each yarn will be rolled up in hasoli. The hasolites are then put into a compound and then rolled in and out between threads that have been stretched as ulos. The process of working on ulos is so continuous that the threads gradually change into a piece of cloth. Throughout the weaving period the body of the weaving craftsman will be tied to the weaving equipment, so that it cannot move freely. The problem in this research is :

1. Most weavers market their work using intermediaries who have an ulos gallery to make it easier for them to get a family income, this is assisted by the gallery owner, the ulos weaving entrepreneur, to be able to sell small-scale production from each community.

2. Direct marketing is done very simply because consumers usually come from the area itself so that the income generated by the ups and downs to meet the needs of daily life.
Published By: \& Sciences Publication

(C) Copyright: All rights reserved.

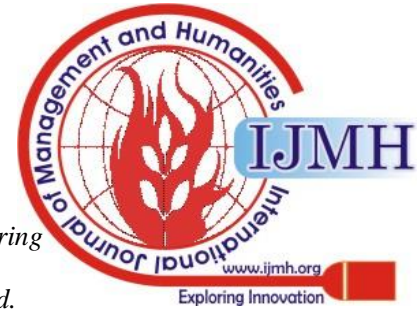



made in household production.

3. The decline in the selling price of ulos woven cloth in the market, the lack of income can reduce productivity due to lack of capital while the price of raw materials is fixed and lack of information obtained by the weaver so that it influences the marketing reach of the ulos produced because do not have a stock of raw materials when raw materials are scarce and prices of raw materials rise in the market, because the weaving industry is still a home industry, so they only dare to buy a small amount in accordance with their capital capabilities.

4. Lack of knowledge of business actors in terms of regulating income and expenditure, resulting in the weavers stop making ulos while they get a capital loan to the place where they leave their products.

\section{LITERATURE REVIEW}

In the regional development effort, it has a fundamental goal to grow the number and variety of job opportunities for the local community. To be able to achieve these objectives, the government and the community jointly take regional development initiatives by using all the potential possessed by the region. According Sirojuzilam (2008: 16) [2] states that economic development as a multidimensional process, which involves major changes, both for changes in economic structure, social, reducing poverty, inequality, and unemployment to economic growth. Differences in various regional conditions have implications for the pattern of development that will be applied.Imitation of a policy pattern that is successfully applied to one region, not necessarily the results can provide the same benefits to other regions. The emphasis of development policy must be adjusted to the characteristics of the region by utilizing the potential of natural resources, human resources, and institutions. The creative economy that is currently developing, especially supported by the digital era, provides significant opportunities for the regional economy to be developed with a variety of renewable resources. According to Helmsing (2001) [3] The current local economy is implemented in the form of partnership partnerships between local governments, communities and the private sector established to manage existing resources to create renewable employment opportunities and boost the economy in various regions. This explains that the management of the small home industry, by exploiting the potential of the local community, cooperation from various relevant institutions and mastery of targeted technology.
Depending on the results they complete ulos fabrics

Determinant Of The Competitiveness Of Creative Industries

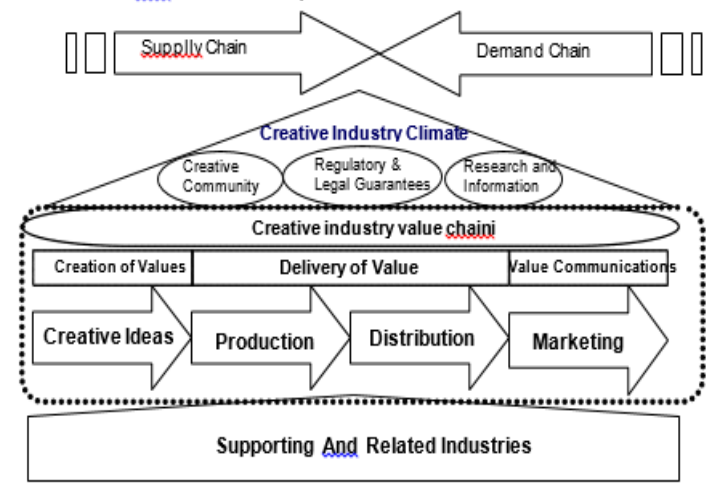

\section{Source: United Nations Conference on Trade and} Development (UNCTAD) in 2007

Developing a creative economy in the region cannot be separated from the local culture which is the main base in terms of its development in the form of local creative products. Creative ideas that emerge are cultural products. For this reason, cultural strategy will determine the direction of creative economic development. Here is an alternative solution to encourage the development of the creative economy so that they are independent and can develop businesses, especially in the regions. In general, each region has potential products that can be raised and developed. The uniqueness or uniqueness of this local product must be the point and then added the element of creativity with a touch of technology.

According to Sadono Sukirno (2010) [4], mathematically the equation of the production function can be described as follows: $\mathrm{Q}=\mathrm{f}(\mathrm{C}, \mathrm{L}, \mathrm{R}, \mathrm{T})$ there are capital, Labour, Resources, Technology, Quantity The concept of mindset can be seen in the following figure :

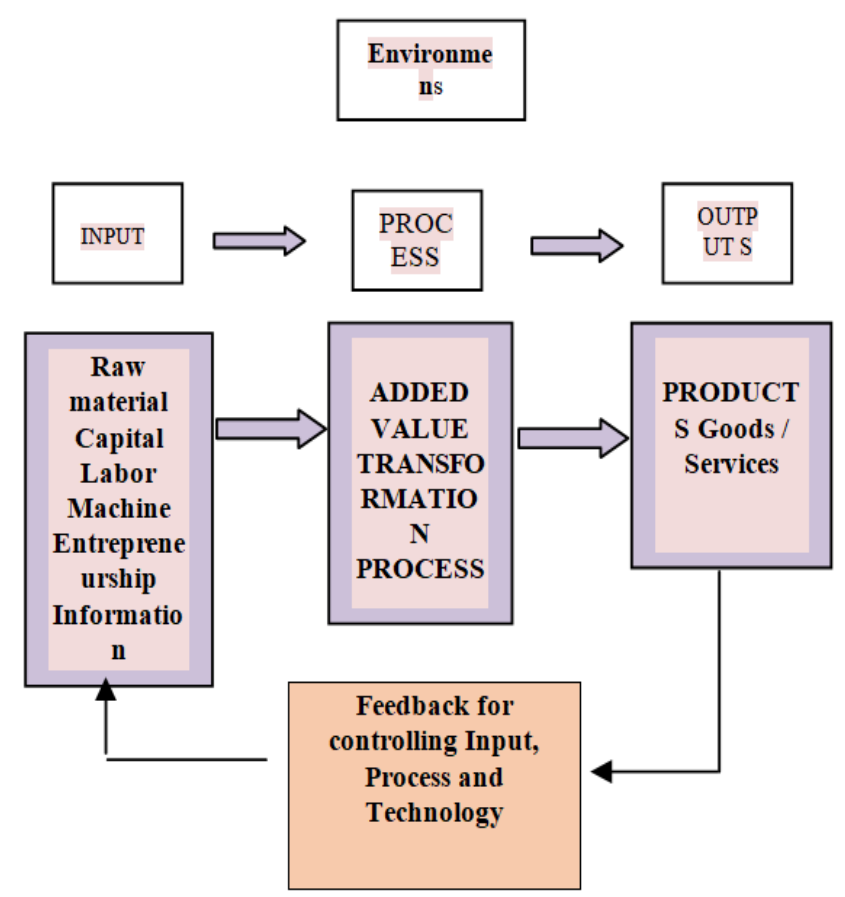

Picture 2.1 : Production Lines

Published By:

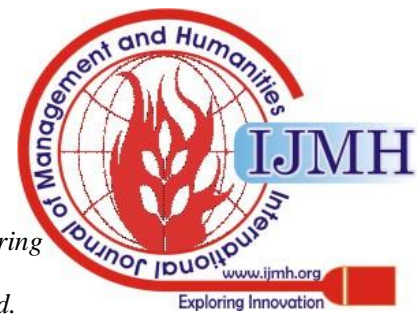


The concept of mindset can be seen in the following figure:

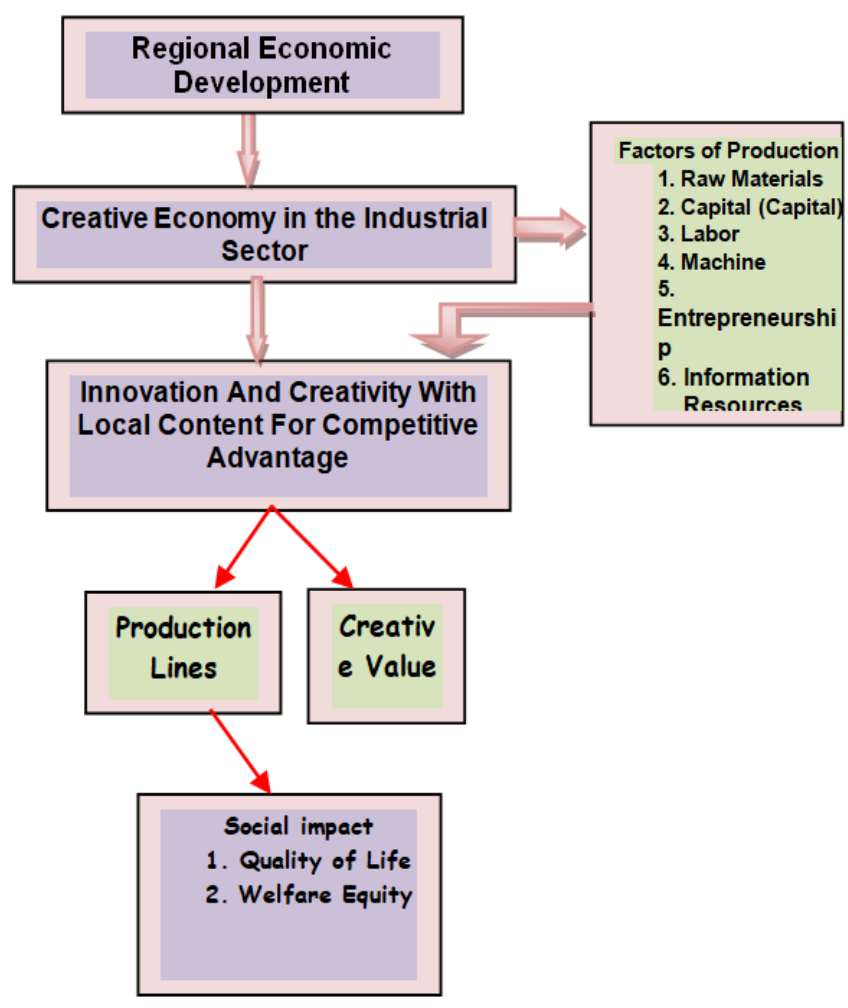

Figure 2.1. Researcher's Thinking Framework

The research concept can be seen in the following figure:
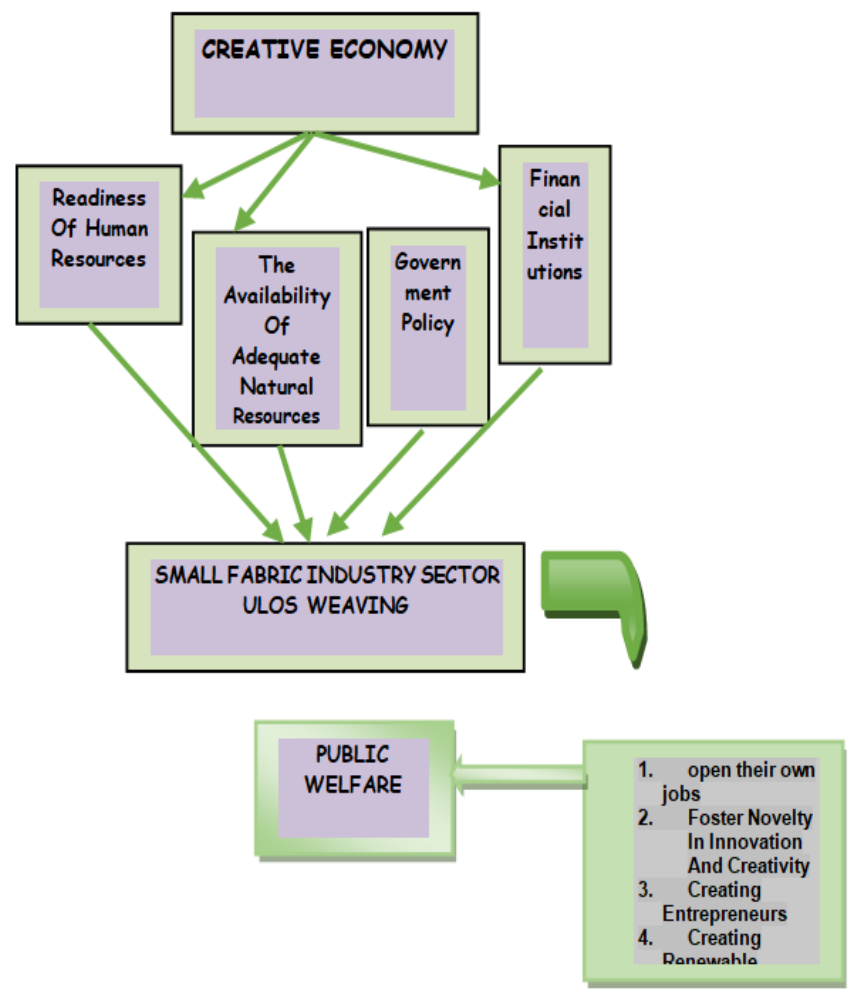

\section{INDENTATIONS AND EQUATIONS}

Data Analysis Method in this research uses Descriptive Analysis and Quantitative Analysis Methods. The parameters discussed are the development of a creative economy that includes readiness of human resources, the availability of adequate natural resources, government policies and financial institutions on special fabrics woven ulos in small industries that include jobs, foster innovation and creativity, find entrepreneurs, and find renewable resources for welfare community in Lumban Suhi-Suhi Village, Samosir Regency. Primary data collection is done by distributing questionnaires to respondents, interviews, and direct observation to the village. Secondary data collection is carried out to find relevant data needed by looking at documents in the office of the village head of Lumban Suhi-Suhi, Pangururan District, Samosir Regency.

\section{FIGURES AND TABLES}

The results of interviews conducted by researchers by weaving craftsmen named (Mrs. Efrina, age 40 years, on September 10, 2019, in the village of Lumban Suhi-Suhi Toruan), explained that, there are three basic elements in human life, namely blood, breath, and hot. The two previous elements are the gift of God, while the third element is not the case. The heat given by the sun is not enough to fend off the cold air in the Batak tribal settlement, especially at night. According to (berta mother, age 45 years, on September 10, 2018, in the village of Lumban Suhi-Suhi Toruan) there are three sources that provide heat to humans, namely the sun, fire and ulos. In addition, ulos serves to provide heat that warms the body and pleases the mind so we are happy to make it. In terms of mengulosi there are rules that must be obeyed, among others, only people can mengulosi those who according to kinship under it. For example, parents may mengulosi children, but children may not mengulosi parents. So in the Batak kinship principle called 'Dalihan Na tolu', which consists of elements of boru hula, and dongan sabutuha, a boru sam is absolutely not required to mengulosi its hula. Ulos given in writing cannot be arbitrary, either in the type or method of making it. The following are some of the traditional tools in making woven fabrics, namely:

1) Breathing bow, made in the form of a crossbow (Sumbia) used for arcing cotton, develops in a uniform condition so that it can be easily made into threads with sorha.

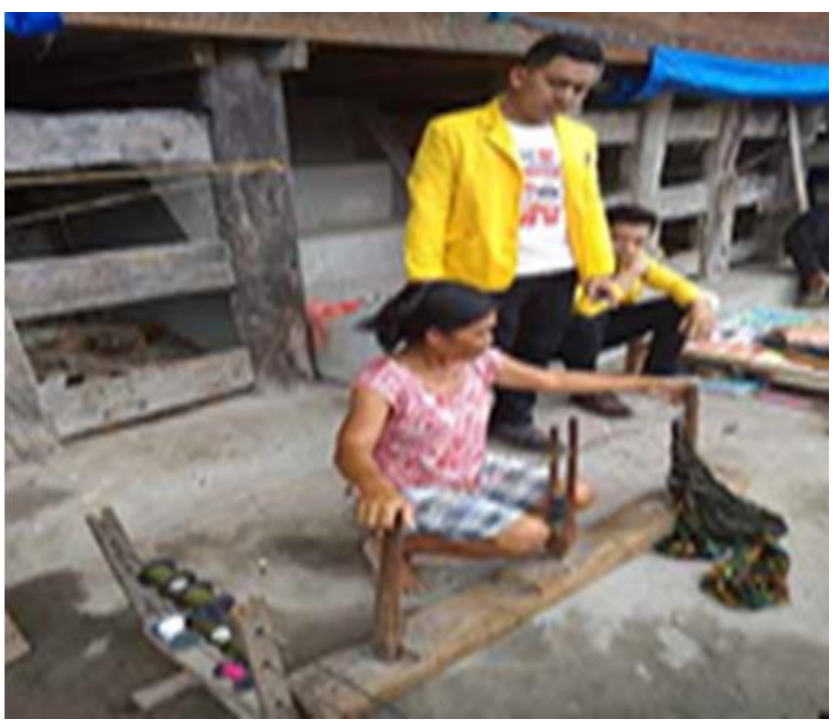

Figure 4.1: (Breathing Bows), For Developing Yarns

Published By:

Blue Eyes Intelligence Engineering

\& Sciences Publication

(C) Copyright: All rights reserved.

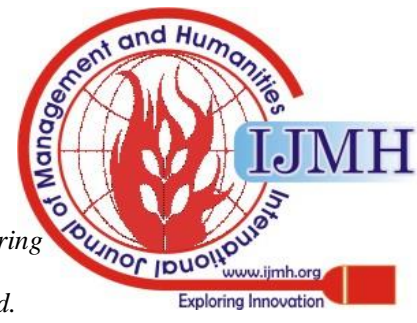


2) Sorhan hands, materials made of wood, boards and iron (wire). Used to spin yarn from cotton. The spinner wheels are moved by hand.

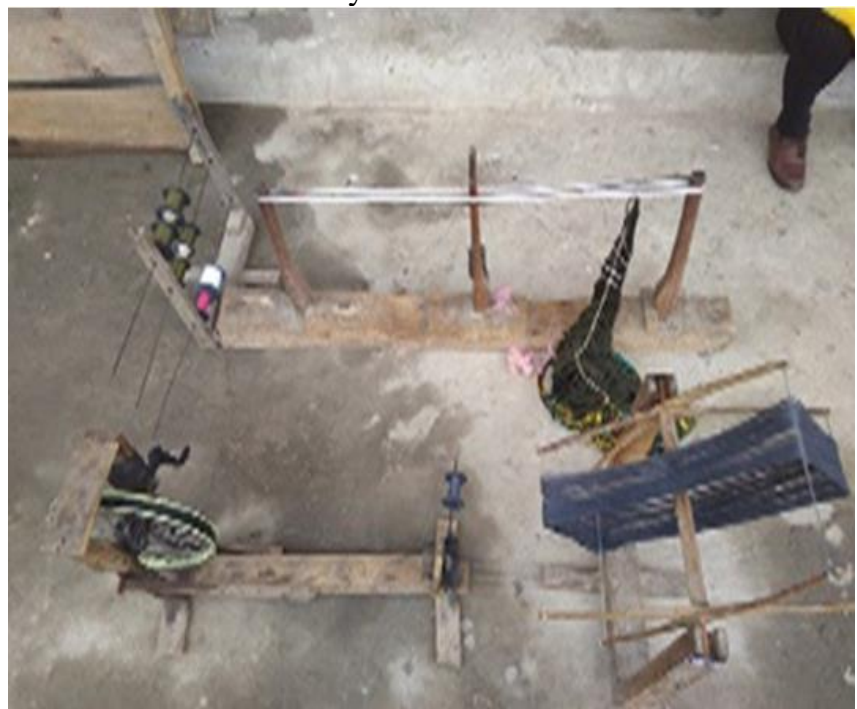

Figure 4.2: (Sorha Hands), For Spinning a Yarn.

3) Erdeng-erdeng, materials from pakko wood and bamboo are used to wind the yarn so that it is easy to move when arranging the diamonds.

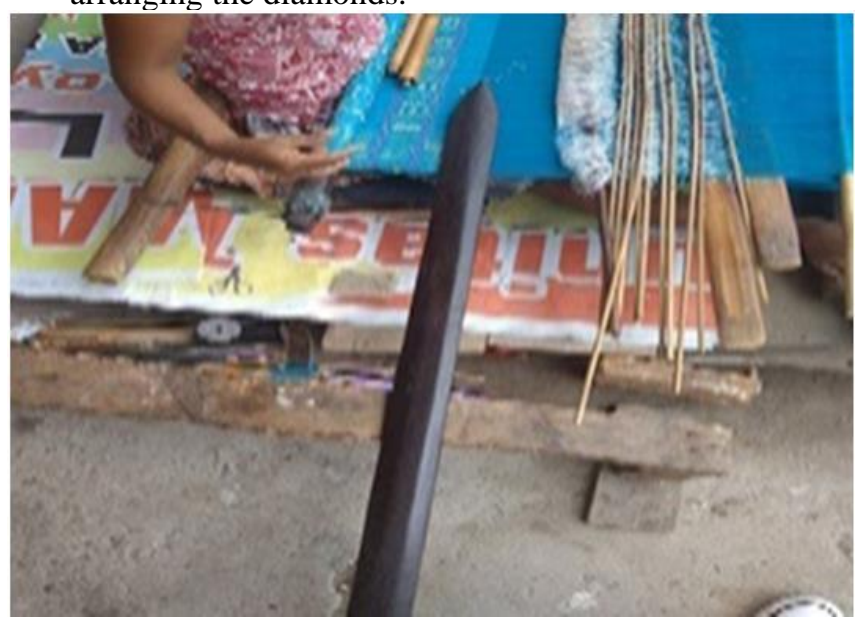

Figure 4.3: (Erdeng-Erdeng), For Arranging Yarns

4) Pangunggasan is made from bamboo, its function is to tense, condense the yarn and as a place to rub the thread with a mixture of starch water and mushy rice.

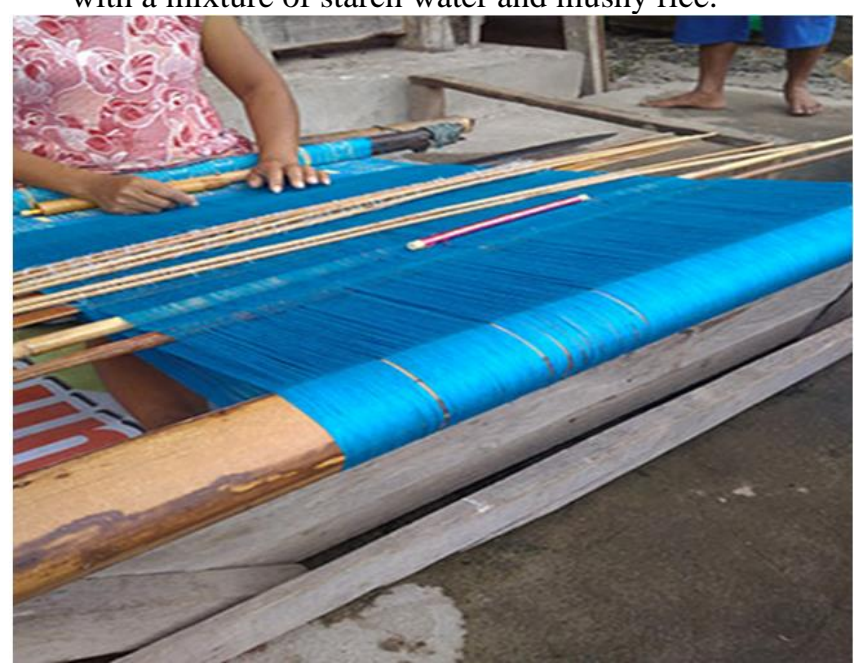

Figure 4.4: (Pangunggasan), for tensing threads
5) Anian is material from jion wood and pakko that are used to assemble yarn before weaving.

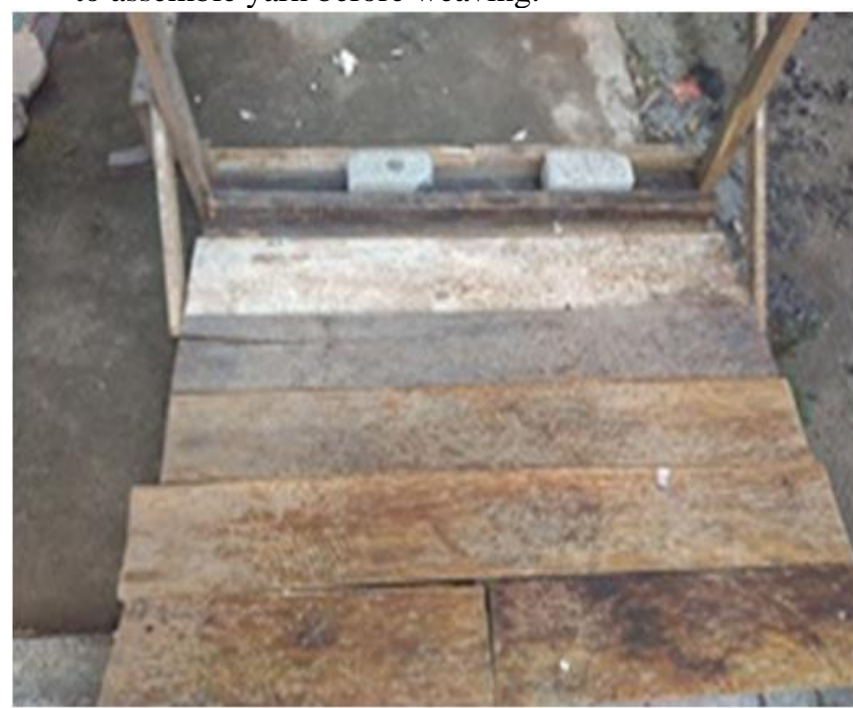

Figure 4.5: (Anian), a tool for assembling yarn before weaving

6) Pagabe is a material from pakko that is used to clamp weaving yarns as well as yarn holders.

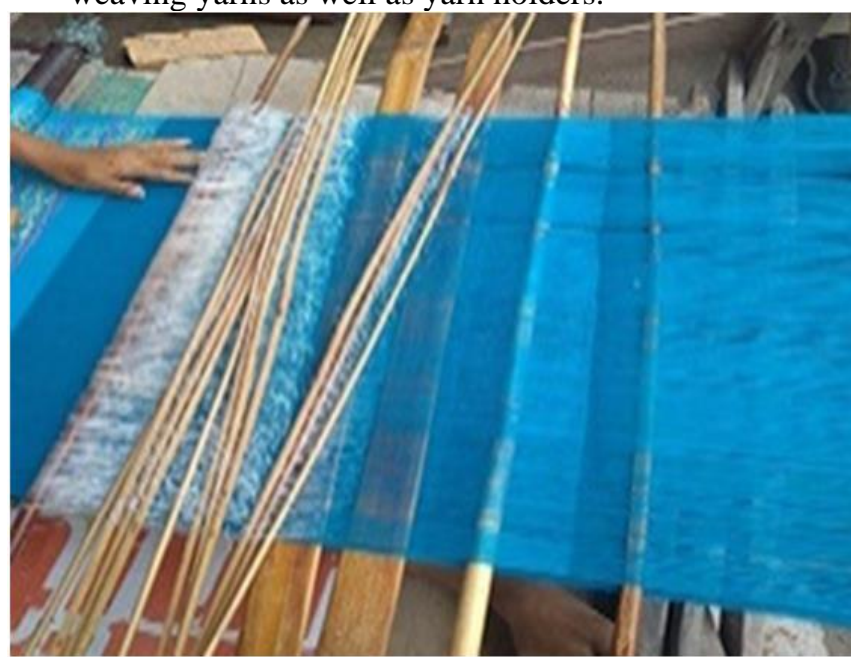

Figure 4.6: (Pagabe), for pinning weaving yarns

Based on the results of research conducted by researchers to woven cloth craftsmen named (Mrs. Monica who was 30 years old when conducting an interview on September 11, 2019, in Lumban Village, Suhi-Suhi Toruan), explained that many woven fabric artisans did not use weaving equipment with modern model. Craftsmen want to maintain the Samosir Batak heritage which always uses traditional looms. If weavers use modern looms, the woven fabric produced is not so typical with traditional tools that have been handed down from generation to generation in the process of making ulos cloth. In addition, traditional looms are also a Batak loom that has cultural values in accordance with the traditional Batak traditional house. Public concern and craftsmen for woven fabrics become a legacy that is always maintained continuously even though technological developments have advanced.

Published By:
\& Sciences Publication

(C) Copyright: All rights reserved.

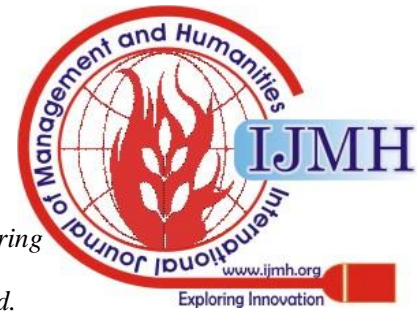




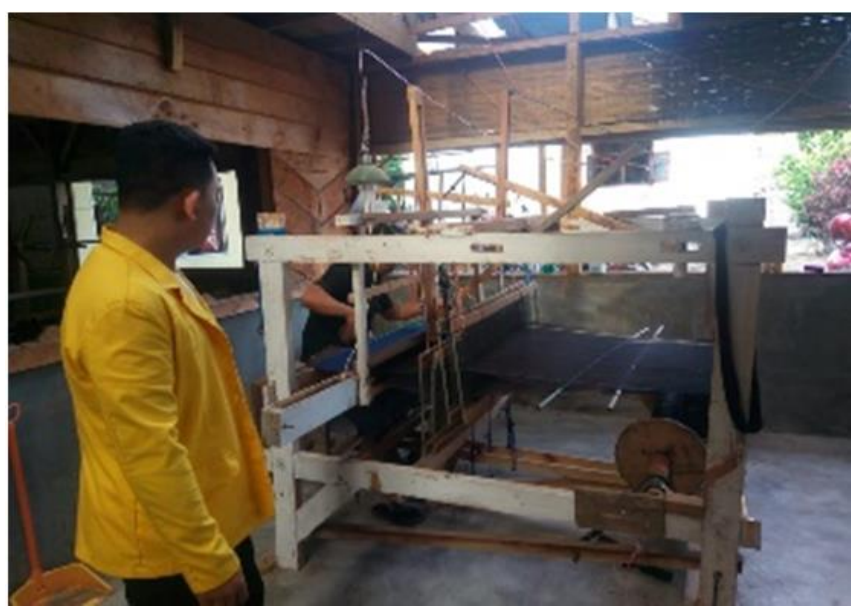

Figure 4.7 Modern loom (Songket Weaving)

In a day Ulos weaving craftsmen do weaving activities for 8 hours to 10 hours a day. Every day weaving craftsmen do cloth manufacturing activities. For weaving craftsmen using traditional tools, weaving work starts from 07.00 am until $17.00 \mathrm{pm}$. But weaving craftsmen don't do it at night. There is a concern when doing ulos weaving. Because traditional ulos craftsmen are family-owned businesses. This means that weavers consist of mothers and children working and inherited from generation to generation. Within a week the craftsman is able to produce one scarf or one sarong. Whereas one dress can finish in two weeks. For shawls by making cloth using turus fur motifs, while clothes and gloves with togu-togu motifs. How to produce ulos cloth is done by sitting on the floor or on a pedestal.

Modern weaving craftsmen is a small industry consisting of a number of craftsmen who work in one big room. Modern weavers are laborers led by ulos business owners. In doing work, weaving craftsmen do work starting at 08.00 am to $18.00 \mathrm{pm}$. Sometimes if there is an order by the consumer the craftsman must weave the fabric until the evening at 21:00 $\mathrm{pm}$. There is a break in working on woven fabric and Sunday is a day off for weaving craftsmen. In making Ulos cloth, the craftsmen are able to produce a shawl or a sarong within 3 to 4 days. As for the clothes the craftsman is able to finish in a week or so. The length of time to manufacture woven fabric depends on the quality of the fabric and the complexity of making ulos. How to produce ulos weaving is done by sitting in a chair. A tool to use the hands and feet to make ulos cloth. The sales system is carried out by the craftsmen business owners who are usually sold directly to Samosir District or to the Samosir tourism office.

From the results of research conducted to weaving craftsmen (Mrs. Wenti, 35 years old, on September 10, 2019, in Lumban Suhi-Suhi Toruan Village), related to government policies on woven fabric craftsmen it was explained that, the development of ulos woven cloths in Lumban Suhi Village Suhi Toruan is still lacking. This is seen from the marketing system carried out individually. Then the craftsman income is still low. So the craftsmen have not obtained welfare in meeting family needs.

The following explanation is related to the Samosir Regency government assistance in the development of ulos woven fabrics, namely:

a. In developing the ulos cloth, various major events have been introduced in the local community, even the marketing of the ulos cloth has reached the international world with the help of the Samosir District Tourism Office. b. Woven cloth craftsmen receive assistance in the form of modern looms which are given to the mothers' association in Lumban Suhi-Suhi Toruan Village. Woven cloth craftsmen do not receive assistance in the form of sewing machines because the craftsmen prefer traditional tools in making ulos cloth. The traditional tool has a name in accordance with the Batak language that has existed since ancient times such as separate equipment that has the appropriate name. In addition, traditional tools in making woven fabrics are quite unique so that they can attract foreign tourists to see them.

c. The Samosir Regency government plan in establishing Small and Medium Enterprises (UKM) in Lumban Suhi-Suhi Toruan Village. The aim is to preserve ulos cloth as well as to develop marketing of ulos cloth. The good impact for weaving craftsmen is that the craftsmen can sell ulos cloth at the selling price. In addition, craftsmen do not need to sell to collectors because they do not sell. Many of the benefits of the establishment of Small and Medium Enterprises (UKM) in Lumban Suhi-Suhi Toruan Village are related to UKM activities. Activities that benefit in introducing and marketing such as exhibitions, introductions in learning to weave ulos, the presence of various other ulos fabric accessories and many other activities related to marketing development of ulos cloth.

Ulos marketing becomes an influence on selling prices due to marketing limitations. over time through the establishment of Small and Medium Enterprises (SMEs) in this village, can help the distribution of Ulos to Samosir District, online and foreign sales. Many weaving craftsmen know the technological development of online marketing. Difficult geographical location and distant access to distribution from rural areas to cities is still a problem. Weaving craftsmen in several places visited have used sophisticated gadgets to see marketing developments. The technology used by young craftsmen can learn the development system and the flow of goods trade digitally with various forms of payment. This can give birth to online marketing ideas for millennial generation weaving craftsmen. The following are the differences in the prices of woven fabrics sold to collectors and users, namely:

d. For ulos collectors, for the price in selling woven fabric, ulos craftsmen sell to collectors at a price of around Rp. 300,000 - up to Rp. 500,000, - for ulos with standard silk threads. Whereas high quality ulos cloth craftsmen sell at prices between Rp.600,000 to Rp.1,000,000, which can be sold directly to ulos collectors in Lumban Village, Suhi-Suhi Toruan. Ulos collectors buy cheaply because collectors also sell ulos again to Samosir Regency so that ulos collectors are intermediaries selling ulos to Samosir Regency. Not a few ulos craftsmen sell to collectors. This is because there are limited craftsmen to sell due to the far access to Samosir Regency. In addition, the Samosir area encompassed by a landscape makes this village area very limited with access to marketing that is crowded. t and $\mathrm{Hu}$ कี 
e. For ulos users, in addition to selling ulos cloth to users, craftsmen sell low-quality ulos cloth at a price of Rp. 500,000 to Rp. 1,000,000 for one ulos scarf. Meanwhile ulos made from rayon with a level of complexity is sold at a price of between Rp. 1,000,000 up to Rp. 1,500,000 for ulos shawls. The price of ulos is expensive because it takes between 4 days to 7 days to complete the ulos. For ulos, craftsman clothes sell for between Rp.2,000,000 and Rp.2,500,000 for one ulos shirt. This is because in making clothes ulos takes a long time to finish for 2 weeks. The reason for ulos old clothes to be finished is because the fabric is made wide and the raw material needed is $2 \mathrm{~kg}$ of fine thread.

\section{CONCLUSION}

In the process of managing ulos that ikat is a traditional weaving tool used by craftsmen in the village of Lumban Suhi-Suhi Toruan. This ikat is a weaving tool that has existed and has been passed down to children for generations. Songket weaving is a modern loom used in small industries in the Lumban Village of Suhi-Suhi Toruan. This machine is driven using hands and feet to weave. In making Ulos fabric, the craftsman of fabric requires raw material for yarn as much as $1.5 \mathrm{~kg}$ of raw material for fine silk yarn. In obtaining raw materials, the craftsmen buy yarn from the yarn collector when making ulos. In making Ulos shawl, craftsmen need raw materials of $1 \mathrm{~kg}$ of fine yarn. Then for the manufacture of craftsman clothes requires raw materials weighing $2 \mathrm{~kg}$ of fine yarn. In the long process of craftsman ikat weaving is able to complete one ulos scarf in less than 1 week of completion. While in making ikat cloth craftsmen clothes are able to complete within 2 weeks for 1 ulos shirt.

In the development of ulos, the process of selling ulos cloth is done by craftsmen selling at relatively expensive prices, such as the ulos shawl of craftsmen selling at Rp.500,000 to local and foreign tourist visitors. As for ulos clothes, craftsmen sell prices of more than Rp. 1,000,000 to visitors. In marketing ulos, weaving craftsmen are able to market ulos with the help of the tourism office. So ulos sales can be marketed to various regions of Indonesia and Abroad. Weaving craftsmen every day in weaving activities get a net income of between Rp. 2,000,000 to Rp. 2,500,000 in one month. Yarns used by craftsmen are fine yarn consisting of silk yarn, rayon yarn, and flash thread. The price sold by the craftsmen depends on the quality of the yarn and the complexity of the craftsmen in making ulos. Many motifs made by ulos weaving craftsmen are hotang yeast motifs used for weddings, sibolang motifs used for events of death and many other motifs. For government policy that is being planned is to establish Small and Medium Enterprises (SMEs).

This goal is so that ulos that are ready can be sold to visitors who come. Ulos marketing process is done by waiting for tourist visitors to come to the village. In addition there are also ulos marketed with the assistance of the Samosir District Tourism Office so that the distribution of ulos can be distributed to foreign countries. Ulos marketing by weaving craftsmen becomes an important role so that weaving craftsmen can get a good income. the marketing system carried out by ulos weaving craftsmen, namely:

1) Individual marketing, weaving craftsmen sell ulos individually by selling to tourist visitors, ordering ulos by consumers from outside the City. And ulos collectors who often come to this village. The activity of craftsmen in marketing ulos is still a problem today. This is because the ulos craftsmen are not able to sell ulos to Samosir Regency. The long distance makes ulos marketing done in front of the house. This means that there are artisans doing weaving ulos, where there are ulos that have become used fabrics.

2) Marketing by the Samosir Regency government, in helping ulos weaving craftsmen to do marketing easily. So the Samosir Regency government helped sell ulos to Samosir Regency. Marketing is carried out by the government by opening a business in the form of an exhibition of Micro and Small and Medium Enterprises (MSMEs) and an art and cultural seller activity in Samosir Regency. In order to sell ulos, Samosir Regency government can collect ulos that are ready for sale and offer training to several weaving craftsmen. This aim is to develop ulos into an art and culture that has a variety of ulos-designed products to attract consumers and tourists alike. It is not every day that ulos marketing activities are carried out by the government only when there are big events and events.

3) Marketing by the Samosir Regency tourism office, in marketing activities carried out by the weaving craftsman tourism office, receives an ease in distributing ulos to various regions in Indonesia. This goal makes it easy for weaving craftsmen because the government is still planning the establishment of Small and Medium Enterprises (UKM) in Lumban Sui-Suhi Toruan Village. In a limitation faced by weaving craftsmen in marketing ulos. The craftsmen are the power of making ulos which always work by not moving around Samosir. The inability in marketing ulos is not the expertise of craftsmen. Moreover, the geographical location surrounded by vast landscapes makes marketing ulos a problem of this village. But the tourism office as a duty and obligation for arts and culture has distributed ulos in a large event. In addition, ulos have been distributed to foreign countries. The introduction of ulos to tourism is able to make ulos as a typical Batak art and culture.

\section{REFERENCES}

1. Marissa Cory Agustina Siagian. 2016. Ulos Hotang Yeast In Change (Portrait Of Toba Batak Culture Evolution.

2. Sirojuzilam, 2008. Economic Disparity And Regional Planning, Economic Inequality In The West Region And East Region Of North Sumatra Province. National Library Of Indonesia Press.

3. Helmsing, A.H.J. 2001. Local Economic Development: New Generations Of Factors, Policies And Instruments. Paper Presented At The Cape Town Symposium.

4. Sukirno, Sadono. 2010. Macroeconomics, Introduction Theory. Jakarta: Pt. Raja Grafindo Persada.

5. Ahyari, A. 2002. Production Management Planning Production System Book 1, Fourth Edition. Yogyakarta: BPFE UGM.

6. Arikunto, Suharsimi. 2010. Research Procedure A Practical Approach. Jakarta: Rineka Cipta.

7. Arsyad, L. 1999. Introduction to Regional Economic Planning and Development, First Edition. Yogyakarta: BPFE.

8. Creative Economy Agency (Bekraf). 2016. Statistics and Results of the Creative Economy Survey 2016. Cooperation of the Creative Economy Agency (Bekraf) and the Central Statistics Agency (BPS)

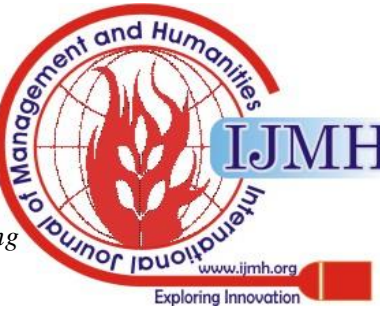




\section{AUTHORS PROFILE}

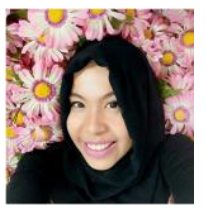

Annisa Ilmi Faried Lubis, completed her Bachelor's education at the Faculty of Social and Political Sciences, Department of State Administration at the Islamic University of North Sumatra. Continuing S2 to Megister of Development Studies, University of North Sumatra, is currently attending further doctoral studies at the University of North Sumatra Economic Studies Program Worked as a teaching staff at the Faculty of Social Science Development Economics Study Program at the Panca Budi Development University (UNPAB) Medan from 2011 until now. Become an expert staff in Balitbang North Sumatra Province by following several research titles. Active in entering national and international journals, one of which is titled Strategy for improving science and welfare through community empowerment technology in the International Journal of Civil Engineering and Technology vol. 9, August 2018. This is my second, the first book titled Innovation in the Current Trend of the Halal Fashion Industry is Increasing in Indonesia and already has IPR. This book is made in connection with research that has been done. Hopefully the readers can add to the treasure of this book.

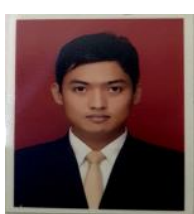

Rahmat Sembiring, Development Economics Study Program at the North Sumatra Islamic University in 2004 completed strata 1 . Then continued to study at the next level at the North Sumatra University Development Study Masters in 2010. Now attending the S3 lecture at the Economics Study Program, North Sumatra University. Worked on the Development Economics Study Program at Medan's Panca Budi Development University in 2011. Actively conducting research to be journalized both nationally and internationally. Becoming an expert staff in Balitbang, North Sumatra Province until now.

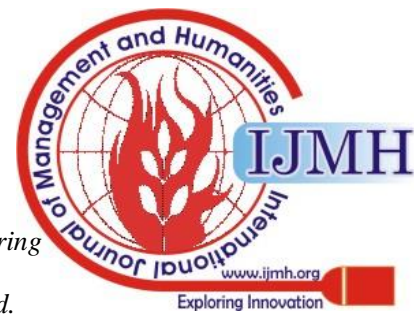

